TITLE:

\title{
Direct and indirect electrochemical generation of alkoxycarbenium ion pools from thioacetals
}

\section{$\operatorname{AUTHOR}(S)$ :}

Matsumoto, Kouichi; Ueoka, Koji; Suzuki, Shinkiti; Suga, Seiji; Yoshida, Jun-ichi

\section{CITATION:}

Matsumoto, Kouichi ... [et al]. Direct and indirect electrochemical generation of alkoxycarbenium ion pools from thioacetals. Tetrahedron 2009, 65 (52): 10901-10907

\section{ISSUE DATE:}

2009-12-26

URL:

http://hdl.handle.net/2433/89513

\section{RIGHT:}

c 2009 Elsevier Ltd. All rights reserved.; この論文は出版社版でありませ ん。引用の際には出版社版をご確認ご利用ください。; This is not the published version. Please cite only the published version. 


\section{Graphical Abstract}

To create your abstract, type over the instructions in the template box below.

Fonts or abstract dimensions should not be changed or altered.

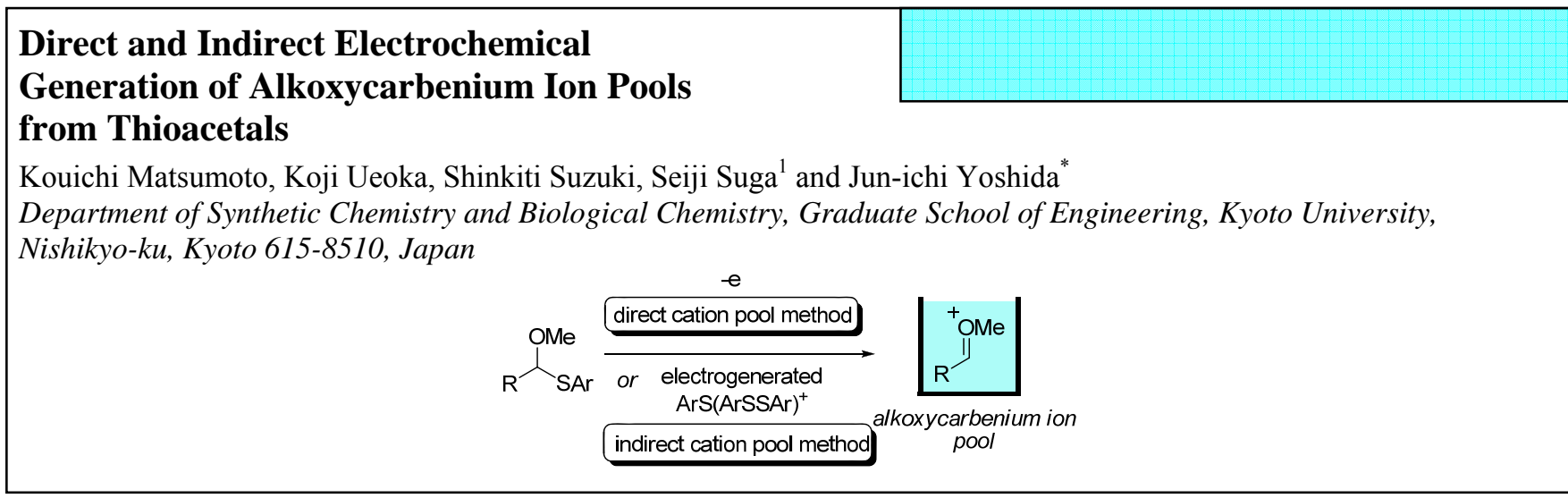




\title{
Direct and Indirect Electrochemical Generation of Alkoxycarbenium Ion Pools from Thioacetals
}

\author{
Kouichi Matsumoto, Koji Ueoka, Shinkiti Suzuki, Seiji Suga ${ }^{1}$ and Jun-ichi Yoshida ${ }^{a^{*}}$ \\ ${ }^{a}$ Department of Synthetic Chemistry and Biological Chemistry, Graduate School of Engineering, Kyoto University, \\ Nishikyo-ku, Kyoto 615-8510, Japan.
}

\begin{abstract}
Thioacetals were found to be effective precursors to generate and accumulate alkoxycarbenium ions based on direct and indirect cation pool methods. Alkoxycarbenium ions thus-generated reacted with carbon nucleophiles such as allylsilanes and enol silyl ethers to give $\mathrm{C}-\mathrm{C}$ bond formation products in good yields.

(C) 2009 Elsevier Science. All rights reserved
\end{abstract}

\section{Introduction}

Alkoxycarbenium ions, carbocations stabilized by a neighboring alkoxy group, are important intermediates in organic synthesis. ${ }^{2}$ Usually alkoxycarbenium ions are generated from acetals using Lewis acids such as $\mathrm{BF}_{3}-\mathrm{OEt}_{2}, \mathrm{SnCl}_{4}$ and $\mathrm{TiCl}_{4}$ in the presence of a nucleophile (Scheme 1). Although benzylic alkoxycarbenium ions and di- and tri(alkoxy)carbenium ions are stable and are well characterized spectroscopically, ${ }^{3}$ simple alkylalkoxycarbenium ions are unstable and are difficult to characterize spectroscopically. The generation processes for such unstable alkoxycarbenium ions are reversible, and their equilibrium concentrations are usually very low. In fact, extensive NMR studies on the reaction of acetals with Lewis acids revealed the presence of Lewis acidacetal complexes, but alkoxycarbenium ions were not detected. ${ }^{4}$

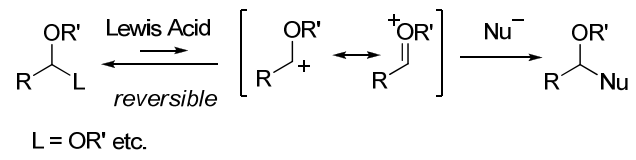

\section{Scheme 1.}

The electrochemical method is also effective for generation of alkoxycarbenium ions. ${ }^{5}$ Recently we have developed the "cation pool" method, in which organic cations are generated and accumulated in the absence of nucleophiles by low-temperature electrolysis. ${ }^{6}$ The cation pool method serves as a powerful tool not only for mechanistic studies on highly reactive organic cations but also for rapid parallel synthesis. The method has been successfully applied to alkoxycarbenium ions, ${ }^{7}$ in addition to $N$-acyliminium ions, ${ }^{8}$ diarylcarbenium ions, ${ }^{9}$ organosilicon cations, ${ }^{10}$ and iodine cations. ${ }^{11} \alpha$-Silyl ethers serve as effective precursors of alkoxycarbenium ion pools (Scheme 2). Silyl groups serve as effective electroauxiliaries, which lower the oxidation potentials and control the regiochemistry by virtue of selective $\mathrm{C}$-Si bond cleavage. ${ }^{12}$ Alkylalkoxycarbenium ions thus-generated are well characterized by NMR spectroscopy, which exhibits very similar spectra to those generated in super acid media. ${ }^{13}$ In the next step, the cations react with carbon nucleophiles such as allylsilanes to give the corresponding carbon-carbon bond formation products.

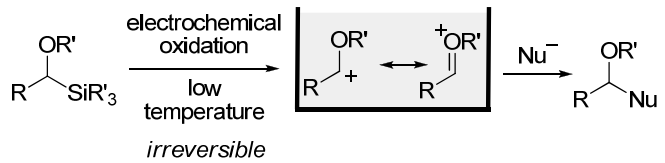

\section{Scheme 2.}

We have been searching for alternative precursors of alkoxycarbenium ion pools and have been interested in thioacetals as precursors because of the following reasons: 1) An arylthio group is also an effective electroauxiliary for electrochemical oxidation. ${ }^{14}$ 2) Thioacetals can be easily prepared. In preliminary communications, ${ }^{15}$ we have reported generation of alkoxycarbenium ion pools from thioacetals by low-temperature electrolysis (direct cation pool method) and by the action of $\operatorname{ArS}(\mathrm{ArSSAr})^{+}$, which is generated by low-temperature electrolysis of ArSSAr (indirect cation pool method) (Scheme 3). In this paper we report full details of these studies.

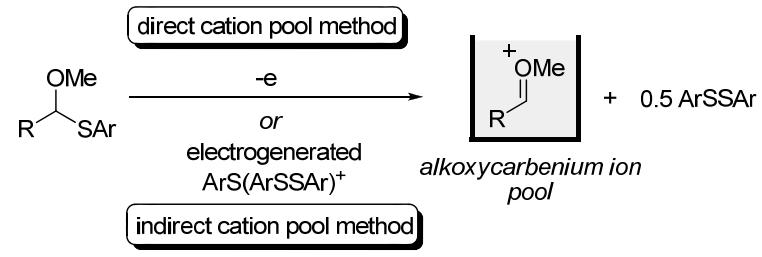

Scheme 3.

\footnotetext{
*Corresponding author. Tel.: +81-75-383-2726; fax: +81-75-383-2727; e-mail: yoshida@sbchem.kyoto-u.ac.jp.
} 


\section{Result and Discussion}

\subsection{Direct Cation Pool Method}

At first, we examined the direct electrochemical method using thioacetal 1 as a precursor of an alkoxycarbenium ion. Thus, a solution of 1 was electrolyzed in $\mathrm{Bu}_{4} \mathrm{NBF}_{4} / \mathrm{CD}_{2} \mathrm{Cl}_{2}$ at $-78{ }^{\circ} \mathrm{C}$ using an H-type divided cell (Scheme 4). After the electrolysis (1.4 $\mathrm{F} / \mathrm{mol}$ ), the resulting solution was analyzed by NMR spectroscopy at $-80{ }^{\circ} \mathrm{C}$. ${ }^{1} \mathrm{H}$ and ${ }^{13} \mathrm{C}$ NMR spectra $\left(-80{ }^{\circ} \mathrm{C}\right)$ indicated the formation of alkoxycarbenium ion (2) by selective cleavage of the $\mathrm{C}-\mathrm{S}$ bond. ${ }^{1} \mathrm{H}$ NMR exhibited a signal at $\delta 9.55 \mathrm{ppm}$ due to the methine proton. ${ }^{13} \mathrm{C}$ NMR exhibited a signal at $\delta 230.9 \mathrm{ppm}$ due to the methine carbon. These chemical shifts are quite similar to those obtained by the direct electrochemical oxidation of $\mathrm{C}_{8} \mathrm{H}_{17} \mathrm{CH}(\mathrm{OMe}) \mathrm{SiMe}_{3}(9.55$ and $231.0 \mathrm{ppm}),{ }^{7 \mathrm{a}}$ suggesting that the alkoxycarbenium ion is efficiently generated and accumulated as a single species in irreversible fashion. Though $\mathrm{PhSSPh}$ is generated by the oxidation of $\mathbf{1}$, the oxidation potential of $\mathbf{1}$ (RDE decomposition potential: $1.30 \mathrm{~V}$ vs. SCE) is lower than that of $\mathrm{PhSSPh}(1.42 \mathrm{~V})$, indicating that PhSSPh cannot be a mediator for the oxidation of 1 .

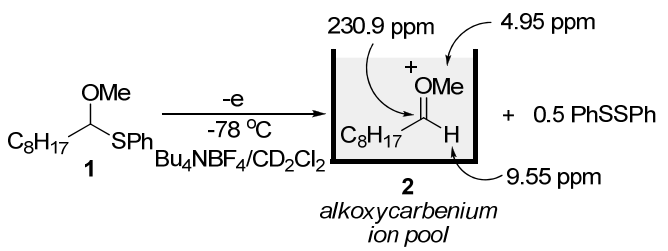

\section{Scheme 4.}

The reaction of 2 with allyltrimethylsilane gave the allylated product 3 in $60 \%$ (Scheme 5). The electrochemical method was found to be applicable to cyclic thioacetals (4 and 5), which were effectively oxidized under similar conditions. After the electrolysis, the resulting solutions were allowed to react with an allylsilane to give the corresponding $\mathrm{C}-\mathrm{C}$ bond formation products 6 and 7 in $82 \%$ and $38 \%$ yields, respectively.

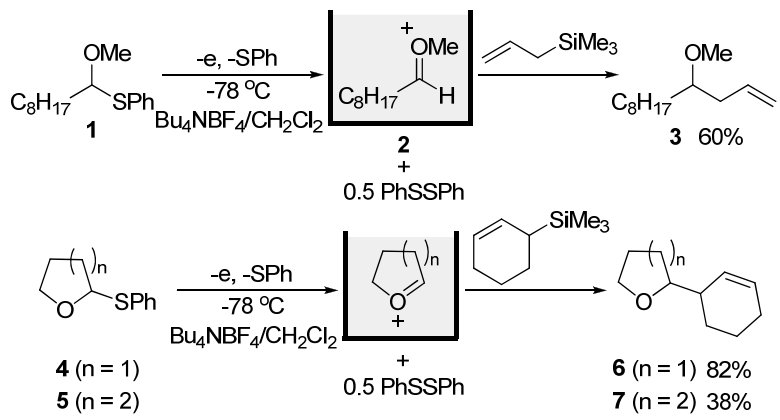

Scheme 5.

\subsection{Indirect Cation Pool Method}

Because electrochemical reactions take place only on the surface of the electrode, alkoxycarbenium ions generated in an early stage of the electrolysis should stay in the solution until the electrolysis is completed. This means the application of direct cation pool method strongly depends on the stability of accumulated alkoxycarbenium ions. ${ }^{16}$ During the accumulation, unstable alkoxycarbenium ions might decompose. To solve this problem, we examined indirect electrochemical method. ${ }^{17}$ In the first step, an active chemical reagent is generated by the electrolysis, which is allowed to react with a precursor to generate an alkoxycarbenium ion pool in the second step. The second reaction can be faster than the electrolysis because it takes place in a homogeneous solution.

We envisaged that "ArS ${ }^{+" 18}$ generated by the electrochemical oxidation of ArSSAr might be suitable for the conversion of thioacetals to alkoxycarbenium ion pools. It is known in the literature that " $\mathrm{ArS}^{+"}{ }^{+19}$ or its equivalent $\mathrm{ArS}(\mathrm{ArSSAr})^{+20}$ serves as a powerful and highly thiophilic reagent, though the nature of the generated species has not yet been fully elucidated. ${ }^{21}$

Thus, the electrolysis of $\operatorname{ArSSAr}\left(\mathrm{Ar}=p-\mathrm{XC}_{6} \mathrm{H}_{4}\right)$ (oxidation potential: $\mathrm{X}=\mathrm{F}: 1.47 \mathrm{~V}, \mathrm{X}=\mathrm{CH}_{3}: 1.34 \mathrm{~V}, \mathrm{X}=\mathrm{OMe}: 1.47 \mathrm{~V}, \mathrm{X}=$ $\mathrm{Cl}: 1.27 \mathrm{~V}, 2$ equiv based on thioacetal 1) was carried out in $\mathrm{Bu}_{4} \mathrm{NBF}_{4} / \mathrm{CH}_{2} \mathrm{Cl}_{2}$ at $-78{ }^{\circ} \mathrm{C}$ using an H-type divided cell (Scheme 6 , step 1). In the next step, the electrogenerated $\operatorname{ArS}(\operatorname{ArSSAr})^{+}$ was reacted with thioacetal $\mathbf{1}$ to generate alkoxycarbenium ion $\mathbf{2}$ (step 2). This process requires only $5 \mathrm{~min}$ at $-78{ }^{\circ} \mathrm{C}$. In the third step, allyltrimethylsilane (10 equiv) was added to obtain the final product 3.

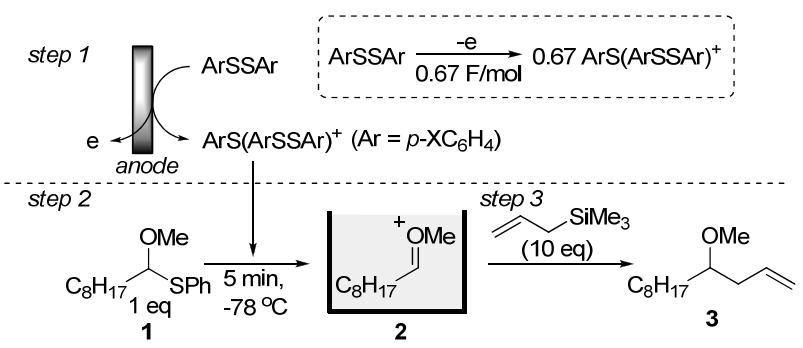

Scheme 6.

The results obtained under various conditions are summarized in Table 1. Electrolysis with $1.34 \mathrm{~F} / \mathrm{mol}$ based on $1(0.67 \mathrm{~F} / \mathrm{mol}$ based on ArSSAr) gave the best yield of 3 (entry 2). $0.67 \mathrm{~F} / \mathrm{mol}$ is the theoretical amount of electricity to convert ArSSAr to $\operatorname{ArS}(\mathrm{ArSSAr})^{+}$. This means that 1.34 equiv of $\mathrm{ArS}(\mathrm{ArSSAr})^{+}$ based on 1 was formed, because 2 equiv of ArSSAr based on 1 was used. Almost quantitative yield of 3 (98\%) suggests that alkoxycarbenium ion 2 was generated almost quantitatively. High reactivity of $\mathrm{ArS}(\mathrm{ArSSAr})^{+}$and homogeneity of the reaction system seem to be responsible for fast and quantitative generation of 2. Use of 1.5 equiv of ArSSAr led to a decrease in the yield of 3 (entry 5). Use of 3.0 equiv of ArSSAr also led to a decrease in the yield of 3 (entry 6). Other $\operatorname{ArSSAr}\left(\mathrm{Ar}=\mathrm{C}_{6} \mathrm{H}_{5}, p-\mathrm{CH}_{3} \mathrm{C}_{6} \mathrm{H}_{4}\right.$, $p$ - $\mathrm{MeOC}_{6} \mathrm{H}_{4}$ and $p-\mathrm{ClC}_{6} \mathrm{H}_{4}$ ) were also effective, although the yield of 3 depends on the nature of the substituent on the aryl group (entries 7-10).

Table 1. Optimization of the indirect cation pool method 


\begin{tabular}{ccccc}
\hline Entry & $\mathrm{X}$ & $\begin{array}{c}\text { ArSSAr } \\
\text { (eq based on 1) }\end{array}$ & $\begin{array}{c}\text { Electricity } \\
\text { (F/mol based } \\
\text { on ArSSAr) }\end{array}$ & $\begin{array}{c}\text { Yield (\%) } \\
\text { of 3 }\end{array}$ \\
\hline 1 & $\mathrm{~F}$ & 2 & 0.50 & 69 \\
2 & $\mathrm{~F}$ & 2 & 0.67 & 98 \\
3 & $\mathrm{~F}$ & 2 & 0.75 & 91 \\
4 & $\mathrm{~F}$ & 2 & 1.0 & 87 \\
5 & $\mathrm{~F}$ & 1.5 & 0.67 & 73 \\
6 & $\mathrm{~F}$ & 3 & 0.67 & 86 \\
7 & $\mathrm{H}$ & 2 & 0.67 & 79 \\
8 & $\mathrm{CH}_{3}$ & 2 & 0.67 & 79 \\
9 & $\mathrm{OMe}$ & 2 & 0.67 & 69 \\
10 & $\mathrm{Cl}$ & 2 & 0.67 & 96 \\
\hline
\end{tabular}

The formation of 2 was confirmed by NMR spectroscopy at -80 ${ }^{\circ} \mathrm{C}$. A solution obtained by the reaction of $\mathbf{1}$ with the electrogenerated $\mathrm{ArS}(\mathrm{ArSSAr})^{+}\left(\mathrm{Ar}=p\right.$ - $\left.\mathrm{FC}_{6} \mathrm{H}_{4}\right)$ exhibited signals at 9.53 and $4.92 \mathrm{ppm}$ due to the methine proton and methyl protons, respectively ( ${ }^{1} \mathrm{H}$ NMR), and a signal at $230.6 \mathrm{ppm}$ due to the methine carbon $\left({ }^{13} \mathrm{C}\right.$ NMR) (Scheme $\left.7 \mathrm{a}\right)$. These chemical shifts are quite similar to those obtained by the direct electrochemical oxidation of $\mathrm{C}_{8} \mathrm{H}_{17} \mathrm{CH}(\mathrm{OMe}) \mathrm{SiMe}_{3}(9.55,4.95$ and $231.0 \mathrm{ppm}){ }^{7 \mathrm{a}}$ Such similarity in chemical shifts indicated that the sulfur-containing byproducts, such as PhSSAr and ArSSAr, which should be present in the solution, did not change the nature of alkoxycarbenium ion 2 appreciably. ${ }^{22}$ We also generated and analyzed an alkoxycarbenium ion by the reaction of 5 with $\operatorname{ArS}(\mathrm{ArSSAr})^{+}\left(\mathrm{Ar}=p-\mathrm{FC}_{6} \mathrm{H}_{4}\right)$. The cation exhibited a signal at $9.86 \mathrm{ppm}$ due to the methine proton $\left({ }^{1} \mathrm{H} \mathrm{NMR}\right)$ and a signal at $227.8 \mathrm{ppm}$ due to the methine carbon $\left({ }^{13} \mathrm{C}\right.$ NMR) (Scheme $\left.7 \mathrm{~b}\right)$.

(a)

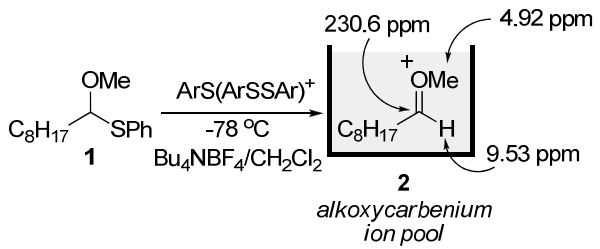

(b)

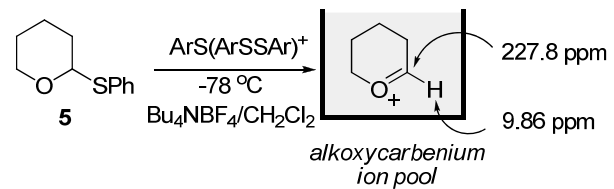

Scheme 7.

The detailed mechanism for the reaction of $\mathbf{1}$ with ArS(ArSSAr) ${ }^{+}$(step 2) has not been clarified as yet, but 2 seems to be generated according to Scheme 8 . Though the possibility of a single electron-transfer mechanism cannot be ruled out, ionic mechanism seems to be more plausible. In the ionic mechanism $\operatorname{ArS}(\operatorname{ArSSAr})^{+}$acted as a thiophilic Lewis acid.

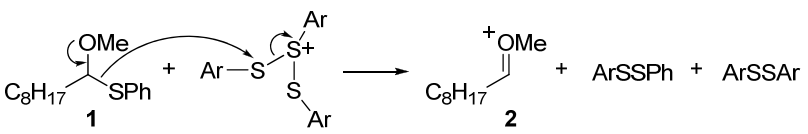

Scheme 8.

In order to get a deeper insight into the mechanism, reactions of 1 with other Lewis acids such as $\mathrm{BF}_{3}-\mathrm{OEt}_{2}$ and $\mathrm{SnCl}_{4}$ were examined. ${ }^{23}$ The resulting solution was analyzed by NMR spectroscopy at $-80{ }^{\circ} \mathrm{C}$, but alkoxycarbenium ion 2 was not detected at all. ${ }^{4}$ Presumably these Lewis acids are not strong enough to generate 2 in a significant concentration. The equilibrium between $\mathbf{1}$ and $\mathbf{2}$ lies to $\mathbf{1}$.

Much lower reactivity of $\mathrm{BF}_{3}-\mathrm{OEt}_{2}$ was confirmed by the following experiments. The reaction of thioacetal (1) with $\operatorname{ArS}(\mathrm{ArSSAr})^{+}\left(\mathrm{Ar}=p-\mathrm{FC}_{6} \mathrm{H}_{4}\right)$ in 5 min followed by treatment with allyltrimethylsilane in $1 \mathrm{~min}$ at $-78^{\circ} \mathrm{C}$ gave 3 in $90 \%$ yield (eq 1). In contrast, the reaction using a $\mathrm{BF}_{3}-\mathrm{OEt}_{2}$ did not give 3 in an appreciable amount under similar conditions (eq 2).

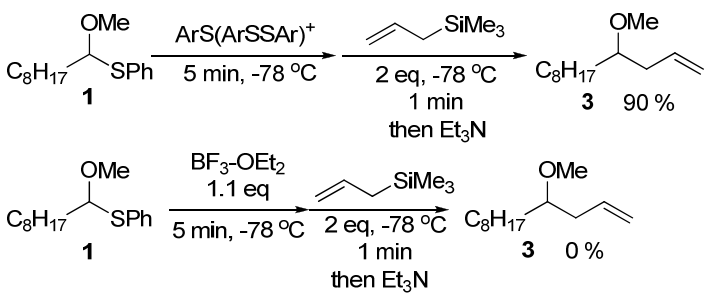

As described above, alkoxycarbenium ion 2 generated by the indirect method exhibited NMR spectra similar to that generated by the direct anodic oxidation of $\mathrm{C}_{8} \mathrm{H}_{17} \mathrm{CH}(\mathrm{OMe}) \mathrm{SiMe}_{3} .{ }^{\text {7a }}$ Thus, we next compared the thermal stability of $\mathbf{2}$ as follows: The cation pool generated at $-78{ }^{\circ} \mathrm{C}$ was allowed to warm to a second temperature. After being kept there for $30 \mathrm{~min}$, the pool was allowed to react with allyltrimethylsilane. The yield of $\mathbf{3}$ is plotted against the temperature in Figure 1. The cation pool of 2 generated by the indirect method exhibited thermal stability similar to that generated by the direct method of $\mathrm{C}_{8} \mathrm{H}_{17} \mathrm{CH}(\mathrm{OMe}) \mathrm{SiMe}_{3}{ }^{7 \mathrm{a}}$

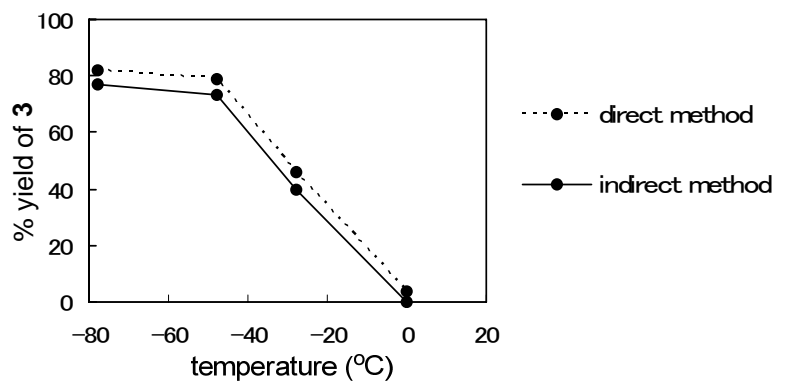

Figure 1. Thermal stability of alkoxycarbenium ion 2 generated by the direct method and the present indirect method.

To test the applicability of the present indirect method, reactions with several carbon nucleophiles were examined (Table 2). Allylsilanes, enol silyl ethers, and ketene silyl acetals, and enol acetate were effective as carbon nucleophiles, and the corresponding $\mathrm{C}-\mathrm{C}$ bond formation products were obtained. 1,3dicarbonyl compounds such as acetylacetone were also effective to form carbon-carbon bond.

Table 2. The reaction of alkoxycarbenium ion with various carbon nuclephiles ${ }^{\text {a) }}$ 


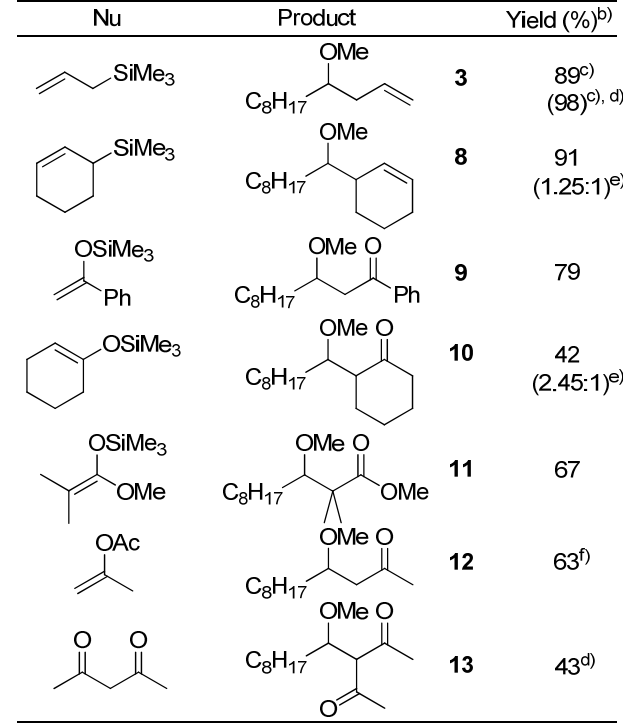

a) $\operatorname{ArSSAr}\left(\mathrm{Ar}=p\right.$ - $\left.\mathrm{FC}_{6} \mathrm{H}_{4}, 0.40 \mathrm{mmol}\right)$ was oxidized electrochemically in $0.3 \mathrm{M} \mathrm{Bu}_{4} \mathrm{NBF}_{4} / \mathrm{CH}_{2} \mathrm{Cl}_{2}$ at $-78{ }^{\circ} \mathrm{C}$ using $0.67 \mathrm{~F} / \mathrm{mol}$ of electricity. The solution thus obtained was allowed to react with $0.20 \mathrm{mmol}$ of thioacetal at $-78{ }^{\circ} \mathrm{C}$ for $5 \mathrm{~min}$. Then a nucleophile $(0.50 \mathrm{mmol}, 2.5$ equiv) was added, and the resulting solution was stirred at $-78^{\circ} \mathrm{C}$ for $15 \mathrm{~min}$ and the reaction was quenched with $\mathrm{Et}_{3} \mathrm{~N}(1 \mathrm{~mL})$. b) Isolated yield. c) GC yield. d) $10 \mathrm{eq}$ of $\mathrm{Nu}$ was used. e) Diastereomer ratio. f) The reaction time with a nucleophile was $30 \mathrm{~min}$.

Table 3. Indirect generation of various alkoxycarbenium ion pools followed by reactions with carbon nucleophiles

Product

a) Isolated yield. b) GC yield. c) The acetal was reacted with

ArS(ArSSAr) ${ }^{+}$for $10 \mathrm{~min}$, the resulting alkoxycarbenium ion was reacted with allyltrimethylsilane for $1 \mathrm{~h}$. d) Diastereomer ratio.

Finally, we examined generation of alkoxycarbenium ion pools from several thioacetals. The $p-\mathrm{ClC}_{6} \mathrm{H}_{4} \mathrm{~S}, p-\mathrm{FC}_{6} \mathrm{H}_{4}$ and $p$ $\mathrm{MeC}_{6} \mathrm{H}_{4} \mathrm{~S}$ groups were also effective as electroauxiliaries. Aryl and alkyl substituted thioacetals, including cyclic substrates, were effective for generation of alkoxycarbenium ion pools. The resulting alkoxycarbenium ion pools reacted with carbon nucleophiles such as allylsilanes to give the corresponding C-C bond formation products in good yields as shown in Table 3.

\section{Conclusions}

In conclusion, we have developed a method for generation and accumulation of alkoxycarbenium ions from thioacetals by direct low-temperature electrolysis. We have also developed a sequential one-pot indirect method for generation and accumulation of alkoxycarbenium ions. In the first step, ArSSAr is oxidized by low temperature electrolysis to generate and accumulate $\operatorname{ArS}(\operatorname{ArSSAr})^{+}$, which is allowed to react with a thioacetal to generate and accumulate an alkoxycarbenium ion. The cation pool thus-generated reacts with various carbon nucleophiles such as allylsilanes and silyl enol ethers. The direct and indirect methods for generation of alkoxycarbenium ion pools from thioacetals add a new dimension to organic cation chemistry and organic electrochemistry.

\section{Experimental Section}

\subsection{General Remarks}

GC analysis was performed on a gas chromatograph (SHIMADZU GC-14B) equipped with a flame ionization detector using a fused silica capillary. ${ }^{1} \mathrm{H}$ and ${ }^{13} \mathrm{C}$ NMR spectra were recorded in $\mathrm{CDCl}_{3}$ on a Varian Gemini $2000\left({ }^{1} \mathrm{H} 300 \mathrm{MHz},{ }^{13} \mathrm{C} 75\right.$ $\mathrm{MHz})$, Varian MERCURY plus-400 $\left({ }^{1} \mathrm{H} 400 \mathrm{MHz},{ }^{13} \mathrm{C} 100 \mathrm{MHz}\right)$, JEOL A-500 $\left({ }^{1} \mathrm{H} 500 \mathrm{MHz},{ }^{13} \mathrm{C} 125 \mathrm{MHz}\right)$, or JEOL ECA-600P $\left({ }^{1} \mathrm{H} 600 \mathrm{MHz},{ }^{13} \mathrm{C} 150 \mathrm{MHz}\right)$ spectrometer with $\mathrm{Me}_{4} \mathrm{Si}$ as an internal standard unless otherwise noted. Mass spectra were obtained on JEOL JMS SX-102A mass spectrometer. IR spectra were measured with a SHIMADZU FTIR 1600 spectrometer. Thinlayer chromatography (TLC) was carried out by using Merck precoated silica gel F254 plates (thickness $0.25 \mathrm{~mm}$ ). Flash chromatography was carried out on a column of silica gel (Kanto Chem. Co., Silica Gel N, spherical, neutral, 40-100 mm). Gel permeation chromatography (GPC) was carried out on Japan Analytical Industry LC-908 equipped with JAIGEL-1H and 2H using $\mathrm{CHCl}_{3}$ as eluent. All reactions were carried out under $\mathrm{Ar}$ atmosphere unless otherwise noted.

\subsection{Materials}

Dichloromethane was washed with water, distilled from $\mathrm{P}_{2} \mathrm{O}_{5}$, redistilled from dried $\mathrm{K}_{2} \mathrm{CO}_{3}$ to remove a trace amount of acid, and stored over molecular sieves 4A. Dry THF was used as obtained (Kanto Chemical Co., Inc.). $\operatorname{ArSSAr}\left(\mathrm{Ar}=p-\mathrm{FC}_{6} \mathrm{H}_{4}\right)$ was prepared according to the procedures in the literatures, ${ }^{24}$ and identified by the comparison of its spectral data with that of authentic sample. ${ }^{25}$

\subsection{Thioacetals}

1-Methoxy-1-phenylthiononane (1) ${ }^{14 \mathrm{c}} \quad 2$ phenylthiotetrahydrofuran $(4)^{26}$ and 2-phenylthiotetrahydropyran $(5)^{26}$ were prepared according to the literature procedures.

\subsubsection{1-Methoxy-1-(4-chlorophenylthio)nonane (14).}

To a solution of 4-chlorobenzenethiol $(5.19 \mathrm{~g}, 36.0 \mathrm{mmol})$ in tetrahydrofuran (THF) $(64 \mathrm{~mL})$, was added triethylamine $(7.2 \mathrm{~mL}$, $52 \mathrm{mmol}$ ) and chloromethyl methyl ether $(3.3 \mathrm{~mL}, 43 \mathrm{mmol})$ at 0 
${ }^{\circ} \mathrm{C}$. After being stirred at room temperature for $2 \mathrm{~h}$, the reaction mixture was partitioned between saturated aqueous $\mathrm{NH}_{4} \mathrm{Cl}$ and ether. The organic phase was separated, washed with saturated aqueous $\mathrm{NaHCO}_{3}$, and was dried over $\mathrm{MgSO}_{4}$. The solvent was removed under reduced pressure and the residue was purified by distillation $\left(130 \quad{ }^{\circ} \mathrm{C}, \quad 14 \mathrm{mmHg}\right), \quad$ to obtain (4chlorophenylthio)methyl methyl ether $(5.76 \mathrm{~g}, 30.5 \mathrm{mmol})$.

To a solution of (4-chlorophenylthio)methyl methyl ether (1.51 $\mathrm{g}, 8.0 \mathrm{mmol})$ in THF $(20 \mathrm{~mL})$, was added butyllithium $(1.54 \mathrm{M}$ in hexane, $6.4 \mathrm{~mL}, 10 \mathrm{mmol}$ ) at $-78{ }^{\circ} \mathrm{C}$. The mixture was stirred at $45^{\circ} \mathrm{C}$ for $3 \mathrm{~h}$ and was cooled to $-78^{\circ} \mathrm{C}$. 1-Iodooctane (2.62 g, 10.9 mmol) was added, and the mixture was stirred at $-78{ }^{\circ} \mathrm{C}$ for 20 min. Saturated aqueous $\mathrm{NH}_{4} \mathrm{Cl}$ was added. The organic materials were extracted with ether, and the organic extracts were washed with brine and dried over $\mathrm{MgSO}_{4}$. After removal of the solvent, the residue was purified by flash chromatography (hexane) to obtain the title compound ( $1.60 \mathrm{~g}, 5.3 \mathrm{mmol}, 66 \%)$ : TLC $R_{f} 0.73$ (hexane/EtOAc 20:1); ${ }^{1} \mathrm{H}$ NMR (400 MHz, $\left.\mathrm{CDCl}_{3}\right) \delta 0.87(\mathrm{t}, J=$ $6.8 \mathrm{~Hz}, 3 \mathrm{H}), 1.21-1.28(\mathrm{~m}, 10 \mathrm{H}), 1.40-1.43(\mathrm{~m}, 2 \mathrm{H}), 1.36-1.44(\mathrm{~m}$, $2 \mathrm{H}), 1.62-1.78(\mathrm{~m}, 2 \mathrm{H}), 3.46(\mathrm{~s}, 3 \mathrm{H}), 4.57(\mathrm{t}, J=6.8 \mathrm{~Hz}, 1 \mathrm{H})$, 7.23-7.26 (m, 2H), 7.36-7.40 (m, 2H); ${ }^{13} \mathrm{C}$ NMR (100 MHz, $\left.\mathrm{CDCl}_{3}\right) \delta 14.2,22.8,26.3,29.2,29.3,29.5,31.9,35.6,55.4,90.9$, 128.7, 131.6, 133.5, 134.6; IR (neat) 2953, 1476, 1130, 1092, 623 $\mathrm{cm}^{-1}$; LRMS (EI) m/z $300\left(\mathrm{M}^{+}\right), 269\left(\mathrm{M}^{+}-\mathrm{OCH}_{3}\right), 187\left(\mathrm{M}^{+}-\mathrm{C}_{8} \mathrm{H}_{17}\right)$, $157\left(\mathrm{M}^{+}-\mathrm{SC}_{6} \mathrm{H}_{4} p-\mathrm{Cl}\right)$; HRMS (EI) calcd for $\mathrm{C}_{16} \mathrm{H}_{25} \mathrm{OClS}$ : 300.1315 , found: 300.1313 .

\subsubsection{1-Methoxy-1-(4-fluorophenylthio)nonane (15).}

To a solution of pelargonaldehyde dimethyl acetal (4.03 g, 21.4 $\mathrm{mmol})$ and $p$-fluorothiophenol $(2.30 \mathrm{~mL}, 21.5 \mathrm{mmol})$ in toluene $(180 \mathrm{~mL})$, was added $\mathrm{BF}_{3}-\mathrm{OEt}_{2}(2.7 \mathrm{~mL}, 21.5 \mathrm{mmol})$ at $-78{ }^{\circ} \mathrm{C}$. The solution was stirred for $2 \mathrm{~h}$. Saturated aqueous $\mathrm{NaHCO}_{3}$ was added. The reaction mixture was partitioned between $\mathrm{Et}_{2} \mathrm{O}$ and saturated aqueous $\mathrm{NaHCO}_{3}$. The organic phase was separated and washed with saturated aqueous $\mathrm{NaHCO}_{3}$ and dried over $\mathrm{MgSO}_{4}$. After removal of the solvent, the crude product was purified by flash chromatography (hexane/EtOAc 30:1) to give the title compound (15) (4.23 g, $14.9 \mathrm{mmol}, 70 \%)$ : TLC $\mathrm{R}_{f} 0.28$ (hexane/EtOAc 20:1); ${ }^{1} \mathrm{H}$ NMR $\left(400 \mathrm{MHz}, \mathrm{CDCl}_{3}\right) \delta 0.87(\mathrm{t}, J=$ $6.8 \mathrm{~Hz}, 3 \mathrm{H}), 1.18-1.32(\mathrm{~m}, 10 \mathrm{H}), 1.34-1.46(\mathrm{~m}, 2 \mathrm{H}), 1.58-1.74(\mathrm{~m}$, $2 \mathrm{H}), 3.47(\mathrm{~s}, 3 \mathrm{H}), 4.51(\mathrm{t}, J=6.4 \mathrm{~Hz}, 1 \mathrm{H}), 6.94-7.02(\mathrm{~m}, 2 \mathrm{H})$, 7.39-7.45 (m, 2H); ${ }^{13} \mathrm{C}$ NMR (75 MHz, $\left.\mathrm{CDCl}_{3}\right) \delta 14.1,22.6,26.2$, $29.1,29.2,29.4,31.8,35.5,55.5,91.0,115.8(\mathrm{~d}, J=21.7 \mathrm{~Hz})$, $127.9(\mathrm{~d}, J=3.4 \mathrm{~Hz}), 136.1(\mathrm{~d}, J=8.0 \mathrm{~Hz}), 162.7(\mathrm{~d}, J=246.0$ $\mathrm{Hz}$ ); IR (neat) 2926, 1590, 1491, $830 \mathrm{~cm}^{-1}$; LRMS (EI) m/z 284 $\left(\mathrm{M}^{+}\right), 157\left(\mathrm{M}^{+}-\mathrm{SC}_{6} \mathrm{H}_{4} p-\mathrm{F}\right)$; HRMS (EI) calcd for $\mathrm{C}_{16} \mathrm{H}_{25} \mathrm{FOS}\left(\mathrm{M}^{+}\right)$ 284.1610, found 284.1605.

\subsubsection{1-Methoxy-1-(4-methylphenylthio)nonane (16).}

To a solution of 4-methylbenzenethiol $(6.13 \mathrm{~g}, 49.4 \mathrm{mmol})$ in THF $(100 \mathrm{~mL})$, was added triethylamine $(10 \mathrm{~mL}, 73 \mathrm{mmol})$ and chloromethyl methyl ether $(4.69 \mathrm{~g}, 58.3 \mathrm{mmol})$ at $0{ }^{\circ} \mathrm{C}$. After being stirred at room temperature for $2 \mathrm{~h}$, the reaction mixture was partitioned between saturated aqueous $\mathrm{NH}_{4} \mathrm{Cl}$ and ether. The organic phase was separated, washed with saturated aqueous $\mathrm{NaHCO}_{3}$, and was dried over $\mathrm{MgSO}_{4}$. The solvent was removed under reduced pressure and the residue was purified by distillation to obtain (4-methylphenylthio)methyl methyl ether (6.71 g, 39.9 mmol).

To a solution of (4-methylphenylthio)methyl methyl ether (3.21 g, $19.1 \mathrm{mmol})$ in THF $(45 \mathrm{~mL})$, was added butyllithium $(1.54 \mathrm{M}$ in hexane, $15 \mathrm{~mL}, 23.1 \mathrm{mmol}$ ) at $-78{ }^{\circ} \mathrm{C}$. The mixture was stirred at $-45{ }^{\circ} \mathrm{C}$ for $3 \mathrm{~h}$ and cooled to $-78{ }^{\circ} \mathrm{C}$. 1-Iodooctane $(5.90 \mathrm{~g}, 24.6$ $\mathrm{mmol}$ ) was added, and the mixture was stirred at $-78{ }^{\circ} \mathrm{C}$ for 30 min. Saturated aqueous $\mathrm{NH}_{4} \mathrm{Cl}$ was added. The organic materials were extracted with ether, and the organic extracts were washed with brine and dried over $\mathrm{MgSO}_{4}$. After removal of the solvent, the residue was purified by flash chromatography (hexane/EtOAc $50: 1)$ to obtain the title compound (4.43 g, $15.8 \mathrm{mmol}, 83 \%$ ): TLC $R_{f} 0.42$ (hexane/EtOAc 20:1); ${ }^{1} \mathrm{H}$ NMR $\left(300 \mathrm{MHz}, \mathrm{CDCl}_{3}\right) \delta$ $0.87(\mathrm{t}, J=6.6 \mathrm{~Hz}, 3 \mathrm{H}), 1.22-1.34(\mathrm{~m}, 10 \mathrm{H}), 1.36-1.52(\mathrm{~m}, 2 \mathrm{H})$, 1.64-1.80 (m, 2H), $2.32(\mathrm{~s}, 3 \mathrm{H}), 3.46(\mathrm{~s}, 3 \mathrm{H}), 4.54(\mathrm{t}, J=6.6 \mathrm{~Hz}$, 1H), $7.09(\mathrm{~m}, 2 \mathrm{H}), 7.35(\mathrm{~m}, 2 \mathrm{H}) ;{ }^{13} \mathrm{C}$ NMR $\left(75 \mathrm{MHz}, \mathrm{CDCl}_{3}\right) \delta$ $14.1,21.1,22.6,26.2,29.1,29.2,29.4,31.8,35.6,55.4,91.1$, 129.4, 129.4, 134.0, 137.5; IR (neat) 2924, 1466, 1088, $644 \mathrm{~cm}^{-1}$; LRMS (EI) m/z $280\left(\mathrm{M}^{+}\right), 157\left(\mathrm{M}^{+}-\mathrm{SC}_{6} \mathrm{H}_{4} p-\mathrm{CH}_{3}\right)$; HRMS (EI) calcd for $\mathrm{C}_{17} \mathrm{H}_{28} \mathrm{OS}: 280.1861$, found: 280.1859 .

\subsection{4. (Methoxy(phenylthio))methylbenzene (17).}

To a toluene solution of benzaldehyde dimethyl acetal ( 786.8 $\mathrm{mg}, 5.17 \mathrm{mmol})$ and thiophenol $(612.0 \mathrm{mg}, 5.55 \mathrm{mmol})$, was added $\mathrm{BF}_{3}-\mathrm{OEt}_{2}(736.0 \mathrm{mg}, 5.19 \mathrm{mmol})$ at $-78{ }^{\circ} \mathrm{C}$. The solution was stirred for $2 \mathrm{~h}$. Dry pyridine $(2.4 \mathrm{~mL})$ was added. The mixture was diluted with ether and was washed with $1 \mathrm{M} \mathrm{NaOH}$ solution and water. After drying over $\mathrm{Na}_{2} \mathrm{SO}_{4}$ and removal of solvent, colorless oil thus obtained was purified by flash chromatography (hexane/EtOAc $50: 1$ to $10: 1$ ) to obtain the title compound (757.8 $\mathrm{mg}, 3.29 \mathrm{mmol}, 64 \%)^{27}$

\subsection{5. (Methoxy(phenylthio)methyl)cyclohexane (19).}

To a toluene solution of cyclohexanecarbaldehyde dimethyl acetal $(774.0 \mathrm{mg}, 4.89 \mathrm{mmol})$ and thiophenol $(600 \mathrm{mg}, 5.45$ mmol) was added $\mathrm{BF}_{3}-\mathrm{OEt}_{2}(901.3 \mathrm{mg}, 6.35 \mathrm{mmol})$ at $-78^{\circ} \mathrm{C}$. The solution was stirred for $2 \mathrm{~h}$, and dry pyridine $(0.5 \mathrm{~mL})$ was added. The mixture was diluted with ether and was washed with $1 \mathrm{M}$ $\mathrm{NaOH}$ solution and water. After drying by $\mathrm{Na}_{2} \mathrm{SO}_{4}$ and removal of solvent, colorless oil thus obtained was purified by flash chromatography (hexane/EtOAc 50:1 to $10: 1$ ) and GPC to give the title compound (918.6 mg, $3.89 \mathrm{mmol}, 79 \%) .{ }^{27}$

\subsection{Generation of Alkoxycarbenium Ions (Direct Cation Pool Method). Typical Procedure.}

The anodic oxidation was carried out in an H-type divided cell (4G glass filter) equipped with a carbon felt anode (Nippon Carbon JF-20-P7, ca. $320 \mathrm{mg}$, dried at $250{ }^{\circ} \mathrm{C} / 1 \mathrm{mmHg}$ for $1 \mathrm{~h}$ before use) and a platinum plate cathode ( $40 \mathrm{~mm}$ x $20 \mathrm{~mm})$. In the anodic chamber was placed a solution of 1-methoxy-1phenylthiononane (1) (94.9 $\mathrm{mg}, 0.356 \mathrm{mmol})$ in $0.3 \mathrm{M}$ $\mathrm{Bu}_{4} \mathrm{NBF}_{4} / \mathrm{CH}_{2} \mathrm{Cl}_{2}(8.0 \mathrm{~mL})$. In the cathodic chamber were placed $0.3 \mathrm{M} \mathrm{Bu}_{4} \mathrm{NBF}_{4} / \mathrm{CH}_{2} \mathrm{Cl}_{2}(8.0 \mathrm{~mL})$ and trifluoromethanesulfonic acid $(150.7 \mathrm{mg}, 1.00 \mathrm{mmol})$. The constant current electrolysis $(8$ $\mathrm{mA}$ ) was carried out at $-78{ }^{\circ} \mathrm{C}$ with magnetic stirring until 2.5 $\mathrm{F} / \mathrm{mol}$ of electricity was consumed.

\subsection{NMR Analysis of Alkoxycarbenium Ion (2) based on Direct Cation Pool Method.}

${ }^{1} \mathrm{H}$ and ${ }^{13} \mathrm{C}$ NMR spectra were recorded in $\mathrm{CD}_{2} \mathrm{Cl}_{2}$ on a JEOL A-500 spectrometer. Chemical shifts are reported using methylene signals of $\mathrm{CH}_{2} \mathrm{Cl}_{2}$ at $\delta 5.32\left({ }^{1} \mathrm{H} \mathrm{NMR}\right)$ and $\delta 53.80\left({ }^{13} \mathrm{C} \mathrm{NMR}\right)$ as standards. The anodic oxidation was carried out in a divided cell equipped with a carbon felt anode and a platinum plate cathode. In the anodic chamber were placed a solution of 1-methoxy-1phenylthiononane (1) (49.9 $\mathrm{mg}, 0.187 \mathrm{mmol})$ in $3.7 \mathrm{~mL}$ of $0.3 \mathrm{M}$ 
$\mathrm{Bu}_{4} \mathrm{NBF}_{4} / \mathrm{CD}_{2} \mathrm{Cl}_{2}$. In the cathodic chamber were placed trifluoromethanesulfonic acid $(71.1 \mathrm{mg}, 0.474 \mathrm{mmol})$ and $0.3 \mathrm{M}$ $\mathrm{Bu}_{4} \mathrm{NBF}_{4} / \mathrm{CD}_{2} \mathrm{Cl}_{2}(3.7 \mathrm{~mL})$. The constant current electrolysis $(3.7$ $\mathrm{mA})$ was carried out at $-78{ }^{\circ} \mathrm{C}$ with magnetic stirring. After 1.4 $\mathrm{F} / \mathrm{mol}$ of electricity was consumed, the reaction mixture of the anodic chamber was transferred to a $5 \mathrm{~mm} \varphi \mathrm{NMR}$ tube with a septum cap under $\mathrm{Ar}$ atmosphere at $-78{ }^{\circ} \mathrm{C}$. The NMR measurement was carried out at $-80{ }^{\circ} \mathrm{C}:{ }^{1} \mathrm{H}$ NMR $(500 \mathrm{MHz}$, $\mathrm{CD}_{2} \mathrm{Cl}_{2}$, selected) $\delta 4.95(\mathrm{~s}, 3 \mathrm{H}), 9.55(\mathrm{~s}, 1 \mathrm{H}) ;{ }^{13} \mathrm{C}$ NMR $(125$ $\mathrm{MHz}, \mathrm{CD}_{2} \mathrm{Cl}_{2}$, selected) $\delta 40.7\left(\mathrm{CH}_{3} \mathrm{OCHCH}{ }_{2}\right), 76.1\left(\mathrm{CH}_{3} \mathrm{OCH}\right)$, $230.9\left(\mathrm{CH}_{3} \mathrm{OCH}\right)$. In the NMR spectra the other signals could not be assigned because of overlap of the signals of $\mathrm{Bu}_{4} \mathrm{NBF}_{4}$ used as electrolyte. The signals due to the thiophenyl group leaving from 1 were also observed: ${ }^{1} \mathrm{H}$ NMR $\delta$ 7.2-8.0 (m); ${ }^{13} \mathrm{C}$ NMR $\delta$ 116.5, 119.0, 124.1, 130.3.

\subsection{Reaction of Alkoxycarbenium Ion and Carbon Nucleophiles. 4-Methoxy-dodec-1-ene (3) (A Typical Procedure of Direct Cation Pool Method).}

The electrolysis of 1 (94.9 $\mathrm{mg}, 0.356 \mathrm{mmol})$ was carried out as described above. To the "cation pool" thus generated in the anodic chamber, was added allyltrimethylsilane $(99.7 \mathrm{mg}, 0.873 \mathrm{mmol})$ at $-78{ }^{\circ} \mathrm{C}$ and the reaction mixture was stirred for $15 \mathrm{~min}$. The solvent was removed under reduced pressure and the residue was quickly filtered through a short column $(2 \times 3 \mathrm{~cm})$ of silica gel to remove $\mathrm{Bu}_{4} \mathrm{NBF}_{4}$. The silica gel was washed with ether $(150 \mathrm{~mL})$. The GC analysis of the combined filtrate indicated that $\mathbf{3}$ was formed in $60 \%$ yield $\left(\mathrm{GC}^{t} R 6.3 \mathrm{~min}\right.$, column, OV-1; $0.25 \mathrm{~mm} \mathrm{x}$ $25 \mathrm{~m}$; initial oven temperature, $100{ }^{\circ} \mathrm{C}$; rate of temperature increase, $10{ }^{\circ} \mathrm{C} / \mathrm{min}$ ). The isolated product was identified by the comparison of its spectral data with those of an authentic sample. $^{7 \mathrm{a}}$

\subsection{Generation of Alkoxycarbenium Ions (Indirect Cation Pool Method). Typical Procedure.}

The anodic oxidation was carried out in an Htype divided cell ( $4 \mathrm{G}$ glass filter) equipped with a carbon felt anode and a platinum plate cathode $(40 \mathrm{~mm} \times 20 \mathrm{~mm})$. In the anodic chamber was placed a solution of $\operatorname{ArSSAr}\left(\mathrm{Ar}=p-\mathrm{FC}_{6} \mathrm{H}_{4}\right)(101.9 \mathrm{mg}, 0.401$ mmol) in $0.3 \mathrm{M} \mathrm{Bu}_{4} \mathrm{NBF}_{4} / \mathrm{CH}_{2} \mathrm{Cl}_{2}(8.0 \mathrm{~mL})$. In the cathodic chamber were placed $0.3 \mathrm{M} \mathrm{Bu}_{4} \mathrm{NBF}_{4} / \mathrm{CH}_{2} \mathrm{Cl}_{2}(8.0 \mathrm{~mL})$ and trifluoromethanesulfonic acid $(41.0 \mathrm{mg}, 0.273 \mathrm{mmol})$. The constant current electrolysis $(8 \mathrm{~mA})$ was carried out at $-78^{\circ} \mathrm{C}$ with magnetic stirring until $0.67 \mathrm{~F} / \mathrm{mol}$ of electricity was consumed. To the anodic chamber containing electrogenerated $\operatorname{ArS}(\operatorname{ArSSAr})^{+}$, was added 1-methoxy-1-phenylthiononane (1) $(53.3 \mathrm{mg}, 0.200$ $\mathrm{mmol}$ ) and the mixture was stirred for $5 \mathrm{~min}$ at $-78{ }^{\circ} \mathrm{C}$. The solution thus obtained was used for the subsequent reaction.

\subsection{NMR Analysis of Alkoxycarbenium Ion based on Indirect Cation Pool Method.}

\subsubsection{Alkoxycarbenium Ion (2) derived from 1.}

${ }^{1} \mathrm{H}$ and ${ }^{13} \mathrm{C}$ NMR spectra were recorded in $\mathrm{CH}_{2} \mathrm{Cl}_{2} / \mathrm{CD}_{2} \mathrm{Cl}_{2}$ (10:1) on a JEOL ECA600P $\left({ }^{1} \mathrm{H} 600 \mathrm{MHz},{ }^{13} \mathrm{C} 150 \mathrm{MHz}\right)$ spectrometer. The anodic oxidation was carried out in a divided cell equipped with a carbon felt anode and a platinum plate cathode. In the anodic chamber were placed a solution of ArSSAr $\left(\mathrm{Ar}=p-\mathrm{FC}_{6} \mathrm{H}_{4}\right)(81.9 \mathrm{mg}, 0.322 \mathrm{mmol})$ in $4.0 \mathrm{~mL}$ of $0.3 \mathrm{M}$ $\mathrm{Bu}_{4} \mathrm{NBF}_{4} / \mathrm{CH}_{2} \mathrm{Cl}_{2} / \mathrm{CD}_{2} \mathrm{Cl}_{2}$ (10:1). In the cathodic chamber were placed trifluoromethanesulfonic acid (32.4 $\mathrm{mg}, 0.216 \mathrm{mmol})$ and $0.3 \mathrm{M} \mathrm{Bu}_{4} \mathrm{NBF}_{4} / \mathrm{CH}_{2} \mathrm{Cl}_{2} / \mathrm{CD}_{2} \mathrm{Cl}_{2}(10: 1)(4.0 \mathrm{~mL})$. The constant current electrolysis $(4.0 \mathrm{~mA})$ was carried out at $-78{ }^{\circ} \mathrm{C}$ with magnetic stirring. After $0.67 \mathrm{~F} / \mathrm{mol}$ of electricity was consumed, the reaction mixture of the anodic chamber $(0.8 \mathrm{~mL})$ was transferred to a $5 \mathrm{~mm} \phi \mathrm{NMR}$ tube with a septum cap under $\mathrm{Ar}$ atmosphere at $-78{ }^{\circ} \mathrm{C}$. 1-Methoxy-1-phenylthiononane (1) (10.2 $\mathrm{mg}, 0.0383 \mathrm{mmol}$ ) was added and the tube was shaken at the same temperature. The NMR measurement was carried out at $-80{ }^{\circ} \mathrm{C}$. Chemical shifts are reported using methylene signals of $\mathrm{CH}_{2} \mathrm{Cl}_{2}$ at $\delta 5.32\left({ }^{1} \mathrm{H}\right.$ NMR) and $\delta 53.80\left({ }^{13} \mathrm{C} \mathrm{NMR}\right)$ as standards. The huge signal coming from $\mathrm{CH}_{2} \mathrm{Cl}_{2}$ is reduced by usual pulse techniques ${ }^{28}$ : ${ }^{1} \mathrm{H}$ NMR $\left(600 \mathrm{MHz}, \mathrm{CH}_{2} \mathrm{Cl}_{2} / \mathrm{CD}_{2} \mathrm{Cl}_{2} \quad(10: 1)\right.$, selected) $\delta 3.26(\mathrm{t}, J=6.3 \mathrm{~Hz}, 2 \mathrm{H}), 4.92(\mathrm{~s}, 3 \mathrm{H}), 9.53(\mathrm{~s}, 1 \mathrm{H}) ;{ }^{13} \mathrm{C}$ NMR $\left(150 \mathrm{MHz}, \mathrm{CH}_{2} \mathrm{Cl}_{2} / \mathrm{CD}_{2} \mathrm{Cl}_{2} \quad(10: 1)\right.$, selected) $\delta 40.3$ $\left(\mathrm{CH}_{3} \mathrm{OCHCH}{ }_{2}\right), 75.6\left(\mathrm{CH}_{3} \mathrm{OCH}\right), 230.6\left(\mathrm{CH}_{3} \mathrm{OCH}\right)$. Other signals could not be assigned because of overlap with the signals of $\mathrm{Bu}_{4} \mathrm{NBF}_{4}$ used as the electrolyte.

\subsubsection{Alkoxycarbenium Ion derived from 5 .}

The anodic oxidation was carried out in a divided cell equipped with a carbon felt anode and a platinum plate cathode. In the anodic chamber were placed a solution of $\operatorname{ArSSAr}\left(\mathrm{Ar}=p-\mathrm{FC}_{6} \mathrm{H}_{4}\right)$

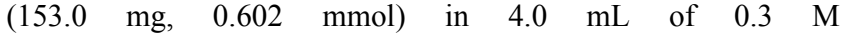
$\mathrm{Bu}_{4} \mathrm{NBF}_{4} / \mathrm{CH}_{2} \mathrm{Cl}_{2} / \mathrm{CD}_{2} \mathrm{Cl}_{2}$ (10:1). In the cathodic chamber were placed trifluoromethanesulfonic acid $(80.2 \mathrm{mg}, 0.534 \mathrm{mmol})$ and $0.3 \mathrm{M} \mathrm{Bu}_{4} \mathrm{NBF}_{4} / \mathrm{CH}_{2} \mathrm{Cl}_{2} / \mathrm{CD}_{2} \mathrm{Cl}_{2}(10: 1)(4.0 \mathrm{~mL})$. The constant current electrolysis $(4.0 \mathrm{~mA})$ was carried out at $-78{ }^{\circ} \mathrm{C}$ with magnetic stirring. After $0.67 \mathrm{~F} / \mathrm{mol}$ of electricity was consumed, the reaction mixture of the anodic chamber $(0.8 \mathrm{~mL})$ was transferred to a $5 \mathrm{~mm} \varphi \mathrm{NMR}$ tube equipped with a septum cap under $\mathrm{Ar}$ atmosphere at $-78{ }^{\circ} \mathrm{C}$. 2-(phenylthio)tetrahydropyran (5) $(16.4 \mathrm{mg}, 0.084 \mathrm{mmol}$ ) was added and the tube was shaken at the same temperature. The NMR measurement was carried out at -80 ${ }^{\circ} \mathrm{C}$. Chemical shifts are reported using methylene signals of $\mathrm{CH}_{2} \mathrm{Cl}_{2}$ at $\delta 5.32\left({ }^{1} \mathrm{H}\right.$ NMR $)$ and $\delta 53.80\left({ }^{13} \mathrm{C} \mathrm{NMR}\right)$ as standards. The huge signal coming from $\mathrm{CH}_{2} \mathrm{Cl}_{2}$ is reduced by usual pulse techniques ${ }^{28}$ : ${ }^{1} \mathrm{H}$ NMR (600 $\mathrm{MHz}, \mathrm{CH}_{2} \mathrm{Cl}_{2} / \mathrm{CD}_{2} \mathrm{Cl}_{2}$ (10:1), selected) $\delta 1.88$ (br t, $J=5.8 \mathrm{~Hz}, 2 \mathrm{H}), 2.14$ (br s, $2 \mathrm{H}), 3.49$ (br t, $J$ $=5.2 \mathrm{~Hz}, 2 \mathrm{H}), 5.24(\mathrm{br} \mathrm{s}, 2 \mathrm{H}), 9.86(\mathrm{~s}, 1 \mathrm{H}) ;{ }^{13} \mathrm{C} \mathrm{NMR}(150 \mathrm{MHz}$, $\mathrm{CH}_{2} \mathrm{Cl}_{2} / \mathrm{CD}_{2} \mathrm{Cl}_{2}(10: 1)$, selected) $\delta 12.1,19.5,35.4,82.5,227.8$. Other signal could not be assigned because of overlap with the signals of $\mathrm{Bu}_{4} \mathrm{NBF}_{4}$ used as the electrolyte or $\mathrm{CH}_{2} \mathrm{Cl}_{2}$, which was uesd as the solvent.

\subsection{Reaction of Alkoxycarbenium Ion and Carbon Nucleophiles. 4-Methoxy-dodec-1-ene (3) (A Typical Procedure of Indirect Cation Pool Method).}

The electrolysis of $\operatorname{ArSSAr}\left(\mathrm{Ar}=p-\mathrm{FC}_{6} \mathrm{H}_{4}\right)(102 \mathrm{mg}, 0.401$ mmol) was carried out as described above. To the $\operatorname{ArS}(\operatorname{ArSSAr})^{+}$ thus generated in the anodic chamber, was added 1-methoxy-1phenylthiononane (1) $(52.7 \mathrm{mg}, 0.198 \mathrm{mmol})$ at $-78{ }^{\circ} \mathrm{C}$ and the reaction mixture was stirred for $5 \mathrm{~min}$. Then allyltrimethysilane $(56.6 \mathrm{mg}, 0.495 \mathrm{mmol}$ ) was added and the resulting solution was stirred at $-78{ }^{\circ} \mathrm{C}$ for $15 \mathrm{~min}$. The reaction was quenched with $\mathrm{Et}_{3} \mathrm{~N}$. The solvent was removed under reduced pressure and the residue was quickly filtered through a short column $(2 \times 3 \mathrm{~cm})$ of silica gel to remove $\mathrm{Bu}_{4} \mathrm{NBF}_{4}$. The silica gel was washed with ether $(150 \mathrm{~mL})$. The $\mathrm{GC}$ analysis of the combined filtrate indicated that the title compound was formed in $89 \%$ yield $\left(\mathrm{GC}{ }^{t} R 7.1 \mathrm{~min}\right.$, column, CBP1; $0.22 \mathrm{~mm} \phi \times 0.25 \mathrm{~mm} \times 25 \mathrm{~m}$; initial oven temperature, $100{ }^{\circ} \mathrm{C}$; rate of temperature increase, $10{ }^{\circ} \mathrm{C} / \mathrm{min}$ ). The isolated product was identified by the comparison of its spectral data with those of an authentic sample. ${ }^{7 \mathrm{a}}$ 
The other products, $6,^{7 \mathrm{a}} 7{ }^{7 \mathrm{a}} \mathbf{8},{ }^{7 \mathrm{a}} \mathbf{9},{ }^{7 \mathrm{a}} \mathbf{1 0},{ }^{7 \mathrm{a}} \mathbf{1 1},{ }^{7 \mathrm{a}} \mathbf{1 2},{ }^{7 \mathrm{a}} \mathbf{1 3},{ }^{7 \mathrm{a}} \mathbf{1 8}^{7 \mathrm{c}}$ and $20^{7 \mathrm{a}}$ were identified by the comparison of their spectral data with those of authentic samples.

\section{Acknowledgments.}

This work was financially supported in part by a Grant-in-Aid for Scientific Research from the Japan Society for the Promotion of Science. The authors thank Prof. Dr. Hendrik Zipse of LudwigMaximilians-Universität München for fruitful discussions. K.M acknowledges JSPS for financial support.

\section{References}

1. Current address: Division of Chemistry and Biochemistry, Graduate School of Natural Science and Technology, Okayama University, 3-1-1 Tsushima-naka, Kita-ku, Okayama 700-8530, Japan

2. For example, Santelli, M.; Pons, J.-M. Lewis Acids and Selectivity in Organic Synthesis; CRC Press: Boca Raton, 1995; Chap 4.

3. Benzylic alkoxycarbenium ions: (a) Rabinovitz, M.; Bruck, D. Tetrahedron Lett. 1971, 245-246. (b) Amyes, T. L.; Jencks, W. P. J. Am. Chem. Soc. 1989, 111, 7888-7900. (c) Jagannadham, V.; Amyes, T. L.; Richard, J. P. J. Am. Chem. Soc. 1993, 115, 8465-8466. (d) Mayr, H.; Gorath, G. J. Am. Chem. Soc. 1995, 117, 7862-7868. Di- and trialkoxycarbenium ions: (e) Ramsey, B. G.; Taft, R. W. J. Am. Chem. Soc. 1966, 88, 3058-3063. (f) Steenken, S.; Buschek, J.; McClelland, R. A. J. Am. Chem. Soc. 1986, 108, 28082813. (g) McClelland, R. A.; Steenken, S. J. Am. Chem. Soc. 1988, 110, 5860-5866. (h) Steenken, S.; McClelland, R. A. J. Am. Chem. Soc. 1989, 111, 4967-4973.

4. Denmark, S. E.; Willson, T. M. In Selectivities in Lewis Acid Promoted Reactions; Schinzer, D. Ed.; Kluwer Academic Publishers: Dordrecht, 1989; p 247.

5. (a) Yoshida, J.; Kataoka, K.; Horcajada, R.; Nagaki, A. Chem. Rev. 2008, 108, 2265-2299. (b) Sperry, J. B.; Wright, D. L. Chem. Soc. Rev. 2006, 35, 605-621. (c) Lund, H. J. Electrochem. Soc. 2002, 149, S21-S33. (d) Moeller, K. D. Tetrahedron 2000, 56, 9527-9554.

6. Yoshida, J.; Suga, S. Chem. Eur. J. 2002, 8, 2650-2658.

7. (a) Suga, S.; Suzuki, S.; Yamamoto, A.; Yoshida, J. J. Am. Chem. Soc. 2000, 122, 10244-10245. (b) Suga, S.; Suzuki, S.; Yoshida, J. Org. Lett. 2005, 6, 4717-4720. (c) Okajima, M.; Suga, S.; Itami, K.; Yoshida, J. J. Am. Chem. Soc. 2005, 127, 6930-6931.

8. (a) Yoshida, J.; Suga, S.; Suzuki, S.; Kinomura, N.; Yamamoto, A.; Fujiwara, K. J. Am. Chem. Soc. 1999, 121, 9546-9549. (b) Suga, S.; Okajima, M.; Yoshida, J. Tetrahedron Lett. 2001, 42, 2173-2176. (c) Suga, S.; Suzuki, S.; Yoshida, J. J. Am. Chem. Soc. 2002, 124, 30-31. (d) Suga, S.; Watanabe, M.; Yoshida, J. J. Am. Chem. Soc. 2002, 124, 14824-14825. (e) Suga, S.; Nagaki, A.; Yoshida, J. Chem. Commun. 2003, 354-355. (f) Suga, S.; Nagaki, A.; Tsutsui, Y.; Yoshida, J. Org. Lett. 2003, 5, 945-947. (g) Suga, S.; Kageyama, Y.; Babu, G.; Itami, K.; Yoshida, J. Org. Lett. 2004, 6, 2709-2711. (h) Suga, S.; Suzuki, S.; Maruyama, T.; Yoshida, J. Bull. Chem. Soc. Jpn. 2004, 77, 1545-1554. (i) Suga, S.; Nishida, T.; Yamada, D.; Nagaki, A.; Yoshida, J. J. Am. Chem. Soc. 2004, 126, 14338-14339. (j) Nagaki, A.; Kawamura, K.; Suga, S.; Ando, T.; Sawamoto, M.; Yoshida, J. J. Am. Chem. Soc. 2004, 126, 14702-14703. (k) Suga, S.; Tsutsui, Y.; Nagaki, A.; Yoshida, J. Bull Chem. Soc. Jpn. 2005, 78, 1206-1271. (1) Maruyama, T.; Suga, S.;
Yoshida, J. J. Am. Chem. Soc. 2005, 127, 7324-7325. (m) Nagaki, A.; Togai, M.; Suga, S.; Aoki, N.; Mae, K.; Yoshida, J. J. Am. Chem. Soc. 2005, 127, 11666-11675. (n) Maruyama, T.; Suga, S.; Yoshida, J. Tetrahedron 2006, 62, 6519-6525. (o) Suga, S.; Watanabe, M.; Song, C.-H.; Yoshida, J. Electrochemistry 2006, 74, 672-679. (p) Maruyama, T.; Mizuno, Y.; Shimizu, I.; Suga, S.; Yoshida, J. J. Am. Chem. Soc. 2007, 129, 1902-1903. (q) Suga, S.; Shimizu, I.; Ashikari, Y.; Mizuno, Y.; Maruyama, T.; Yoshida, J. Chem. Lett. 2008, 37, 1008-1009.

9. (a) Okajima, M.; Soga, K.; Nokami, T.; Suga, S.; Yoshida, J. Org. Lett. 2006, 8, 5005-5007. (b) Nokami, T.; Ohata, K.; Inoue, M.; Tsuyama, H.; Shibuya, A.: Soga, K.; Okajima, M.; Suga, S.; Yoshida, J. J. Am. Chem. Soc. 2008, 130, 1086410865. (c) Okajima, M.; Soga, K.; Watanabe, T.; Terao, K.; Nokami, T.; Suga, S.; Yoshida, J. Bull. Chem. Soc. Jpn. 2009, 82, 594-599.

10. Nokami, T.; Soma, R.; Yamamoto, Y.; Kamei, T.; Itami, K.; Yoshida, J. Beilstein J. Org. Chem. 2007, 3:7.

11. Midorikawa, K.; Suga, S.; Yoshida, J. Chem. Commun. 2006, 3794-3796.

12. (a) Yoshida, J.; Maekawa, T.; Murata, T.; Matsunaga, S.; Isoe, S. J. Am. Chem. Soc. 1990, 112, 1962-1970. (b) Yoshida, J.; Nishiwaki, K. J. Chem. Soc., Dalton Trans. 1998, 2589-2596.

13. (a) Olah, G. A.; Bollinger, J. M. J. Am. Chem. Soc. 1967, 89, 2993-2996. (b) Olah, G. A.; Sommer, J. J. Am. Chem. Soc. 1968, 90, 4323-4327. (c) Forsyth, D. A.; Osterman, V. M.; DeMember, J. R. J. Am. Chem. Soc. 1985, 107, 818-822.

14. (a) Yoshida, J.; Sugawara, M.; Kise, N. Tetrahedron Lett. 1996, 37, 3157-3160. (b) Sugawara, M.; Mori, K.; Yoshida, J. Electrochim. Acta, 1997, 42, 1995-2003. (c) Yoshida, J.; Sugawara, M.; Tatsumi, M.; Kise, N. J. Org. Chem. 1998, 63, $5950-5961$.

15. (a) Suzuki, S.; Matsumoto, K.; Kawamura, K.; Suga, S.; Yoshida, J. Org. Lett. 2004, 6, 3755-3758. (b) Suga, S.; Matsumoto, K.; Ueoka, K.; Yoshida, J. J. Am. Chem. Soc. 2006, 128, 7710-7711.

16. To solve the problem, we have developed the cation flow method. (a) Suga, S.; Okajima, M.; Fujiwara, K.; Yoshida, J. J. Am. Chem. Soc. 2001, 123, 7941-7942. (b) Suga, S.; Okajima, M.; Fujiwara, K.; Yoshida. J. QSAR Comb. Sci. 2005, 24, 728-741.

17. For indirect electrochemical methods, see: Steckhan, E. Angew. Chem., Int. Ed. Engl. 1986, 25, 683-701.

18. (a) Bewick, A.; Coe, D. E.; Mellor, J. M.; Walton, D. J. J. Chem. Soc., Chem. Commun. 1980, 51-52. (b) Do, Q. T.; Elothmani, D.; Simonet, J.; Le Guillanton, G. Electrochim. Acta 2005, 50, 4792-4799, and references cited therein.

19. For example, (a) Smit, W. A.; Krimer, M. Z.; Vorobieva, E. A. Tetrahedron Lett. 1975, 16, 2451-2454. (b) Capozzi, G.; Lucchini, V.; Modena, G.; Rivetti, F. J. Chem. Soc., Perkin Trans. 2 1975, 361-366.

20. For example, (a) Gybin, A. S.; Smit, W. A.; Bogdanov, V. S.; Krimer, M. Z.; Kalyan, J. B. Tetrahedron Lett. 1980, 21, 383386. (b) Bogdanov, V. S.; Gybin, A. S.; Cherepanova, E. G.; Smith, W. A. Izv. Akad. Nauk Ser. Khim. 1981, 2681-2693.

21. (a) Larsen, A. G.; Holm, A. H.; Roberson, M.; Daasbjerg, K. J. Am. Chem. Soc. 2001, 123, 1723-1729. (b) Brinck, T.; Carlqvist, P.; Holm, A. H.; Daasbjerg, K. J. Phys. Chem. A 2002, 106, 8827-8833. (c) Holm, A. H.; Yusta, L.; Carlqvist, P.; Brinck, T.; Daasbjerg, K. J. Am. Chem. Soc. 2003, 123, 2148-2157.

22. Reactivity of cations: (a) Mayr, H.; Ofial, A. R. Angew. Chem., Int. Ed. 2006, 45, 1844-1854. (b) Hofmann, M.; Hampel, N.; Kanzian, T.; Mayr. H. Angew. Chem., Int. Ed. 2004, 43, 54025405. 
23. (a) Braga, A. L.; Dornelles, L.; Silveira, C. C.; Wessjohann, L. A. Synthesis 1999, 562-564. (b) Sato, T.; Okura, S.; Otera, J.; Nozaki, H. Tetrahedron Lett. 1987, 28, 6299-6302. (c) Nishiyama, H.; Narimatsu, S.; Sakuta, K.; Itoh, K. J. Chem. Soc., Chem. Commun. 1982, 459-460.

24. Leino, R.; Lönnqvist, J. E. Tetrahedron Lett. 2004, 45, 84898491.

25. Becker, D. P.; Villamil, C. I.; Barta, T. E.; Bedell, L. J.; Boehm, T. L.; DeCrescenzo, G. A.; Freskos, J. N.; Getman, D. P.; Hockerman, S.; Heintz, R.; Howard, S. C.; Li, M. H.; McDonald, J. J.; Carron, C. P.; Funckes-Shippy, C. L.; Mehta,
P. P.; Munie, G. E.; Swearingen, C. A. J. Med. Chem. 2005, 48, 6713-6730.

26. Braga, A. L.; Silveira, C. C.; Dornelles, L.; Zeni, G. ; Galarza, F. A. D.; Wessjohann, L. A. Syn. Commun. 1995, 25, 31553162.

27. Sato, T.; Otera, J.; Nozaki, H. Tetrahedron 1989, 45, 12091218.

28. Guéron, M.; Plateau, P.; Decorps, M. Prog. Nucl. Magn. Reson. Spectrosc. 1991, 23, 135-209. 